DOI: $10.19195 / 2084-5065.49 .9$

\title{
An integrated approach to solving the problems of establishing the prescription of the application of handwritten and printed requisites of documents
}

\author{
ELENA LUKINICHNA SHESTEPEROVA \\ Baikal Center of Forensic Expertise and Graphological Analysis \\ Irkutsk, Russia \\ RITA KONSTANTINOVNA ORLOVSKAYA \\ Baikal Center of Forensic Expertise and Graphological Analysis \\ Irkutsk, Russia
}

The increase in living standards and the complexity of economic relations have lead to an increase in the legal awareness of society. More often, in resolving disputes, parts of the legal proceedings use expert opinions as evidence. Often, in order to obtain a quick result, the courts assign expertise on narrow issues to various expert organizations, and various specialists. Consequently, we get disparate conclusions, some of which are conflicting. In the process of carrying out such questioned document examinations, the objective information basis of the document is lost, as it becomes impossible to conduct a further more in-depth study of the requisites of the document.

The pace of scientific and technological progress is such that any scientific knowledge requires constant improvement, in particular, to enhance the professional competence of experts. In addition, today in modern document circulation investigative bodies, courts, and then ex- 
perts face a huge number of options for document forgery. This is due to both the technical and the information capabilities of citizens. When falsifying documents, methods of computer installation, ${ }^{1}$ technical forgery applying other technical means, etc. are used. Objective and correct identification of this range of criminal methods is possible only with a comprehensive approach to the research, both regarding details (requisites) and documents.

In recent decades, there has been a rapid expansion of the range of forensic expertise of documents, often coupled with a significant qualitative change in these objects. This leads to the fact that expert examination of documents based on only traditional knowledge in the sphere of technical examination of documents (TED), within the framework of one type of examination, becomes impossible (or one-sided) and requires knowledge from other related spheres.

This urgent need has determined the use of various means and methods of investigation by forensic experts and specialists to identify falsifications of documents. The more complicated tasks of examination often become fully resolved only due to an integrated expert study.

The question of the admissibility of an integrated document study has been the subject of discussion for some time. It has caused many objections, as experts seemed to outgo beyond their competence and, accordingly, break the principle of personal responsibility of the expert for the conclusion he had come to. However, the practice did not confirm such fears. Now an integrated forensic examination of documents has proven its effectiveness. Both experts and forensic scientists consider it necessary.

Traditional primary visual inspection of a document in forensic examination of the present day is applied through optical microscopy methods. The use of polarizing microscopes, optical digital devices with the possibility of increasing up to 600 times allows you to establish test material with which the requisites of the document are fulfilled. A qualified expert, for example, is sure to distinguish (by the morphology of strokes)

1 A.A. Plinatus, "Sovremennye vozmozhnosti tekhniko-kriminalisticheskogo issledovaniya kopij dokumentov, izgotovlennyh posredstvom montazha", [in:] Kriminalisticheskie sredstva i metody v raskrytii i rassledovanii prestuplenij, vol. 2, EKC MVD Rossii, Moskva 2006, pp. 139-146. 
the details (requisites) made by paste for a ballpoint pen from another test material (pen ink, ink for a gel pen, pencil, etc).

The methods of optical microscopy also make it possible to establish the fact of making requisites with pens that have paste (refill) of different color shades. To confirm the difference in the color shades of the paste, and, consequently, prove the fulfillment of requisites by different writing instruments, is possible with thin-layer chromatography methods by establishing a qualitative composition of the dyes of the writing test material. Traditional thin-layer chromatography methods allow fixing the following information: in one document both notes and signature are made with the pastes for ballpoint pens with a different component dye composition, i.e., different ballpoint pens. Also for these purposes, it is possible to use gas chromatography using mass-selective detectors, and spectrophotometric installations.

The use of these methods undoubtedly increases the reliability of the conclusions in determining the relative limitation of the fulfillment of the details (requisites) of the document.

The study of printed text as one of the requisites allows fixing time intervals for document creation: making some sheets of the document at different periods or one-time making documents with different creation dates. It also allows revealing the fact of computer editing when creating a document. In the elements of the strokes of printed characters it is possible to analyze the dynamics of depletion of the cartridge for its operational period (Fig. 1), to establish asynchronicity (time difference) in making printed text on different sheets of the document (Fig. 2-3), to reveal the fact of computer processing of the image of the document after scanning (Fig. 4).
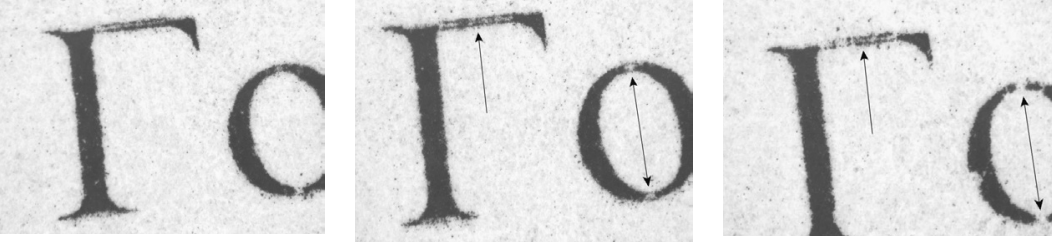

Figure 1. Dynamics of operational period characteristics of a printer ${ }^{2}$

2 All the figures in this article come from different questioned document examinations taken at the Baikal Center of Forensic Expertise and Graphological Analysis. 

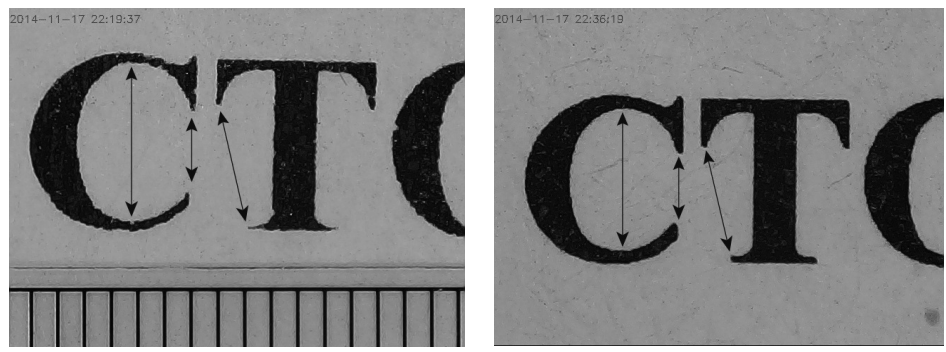

Figure 2. Elements of printed text from the first (left) and second (right) pages of the first copy of the document
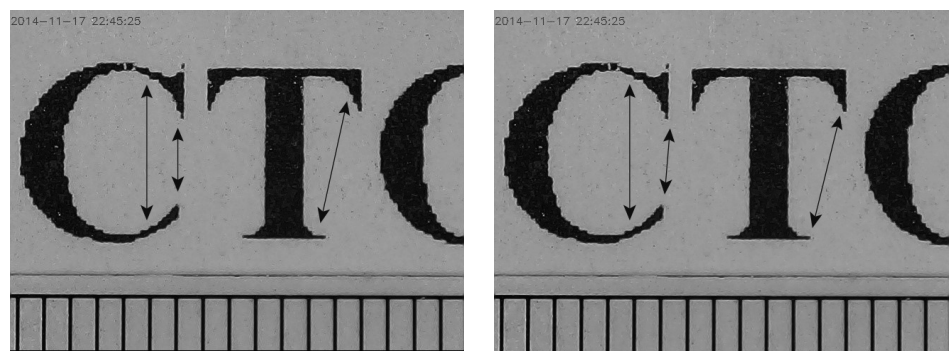

Figure 3. Elements of printed text from the first (left) and second (right) pages of the second copy of the document after computer processing

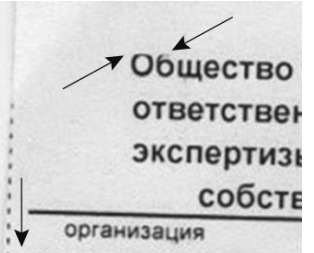

くВИТАНЦИЯ

Figure 4. Symptoms of computer editing when creating a document

With further research, an expert can establish the relative age of execution of requisites: the sequence of applying the printed text, handwritten notes, signatures, and prints. It is possible to fix the sequence of applying the requisites both with zones of mutual intersection and without them. For these purposes, they use direct optical microscopes with a magnification of up to 600 times (Fig. 5-9). 


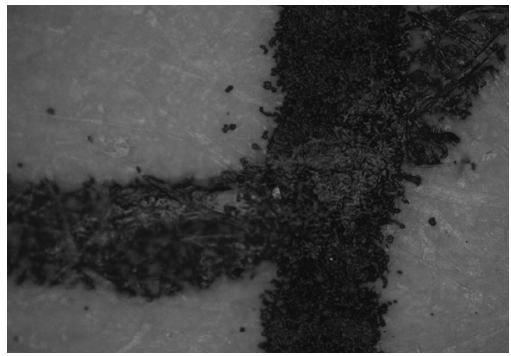

Figure 5. The paste of the ballpoint pen, which has been signed, is located on the stroke of the printed text in the place (zone) of their mutual intersection

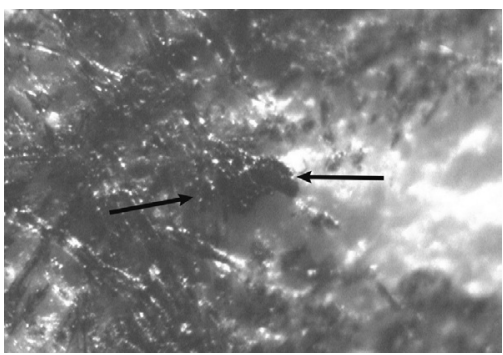

Figure 6. The trace of the balloon unit of the writing device on the toner particle when the sequence of applying requisites is found without the places of mutual intersection of the signature strokes and printed text

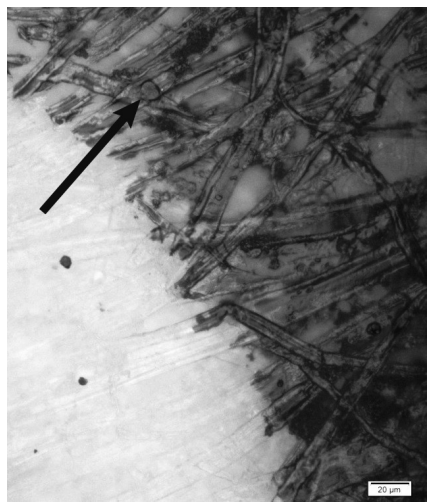

Figure 7. Particles of the coloring matter of the printed text (toner) under the coloring material (ballpoint pen paste) of the note stroke, detected with the Olympus BX51 microscope 


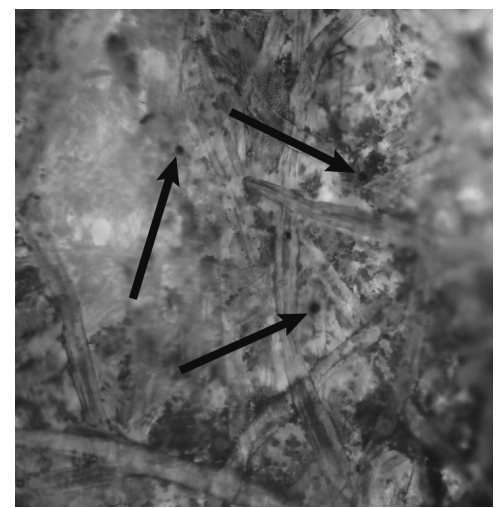

Figure 8. Particles of the coloring matter of the printed text (toner) under the coloring material BX51 microscope

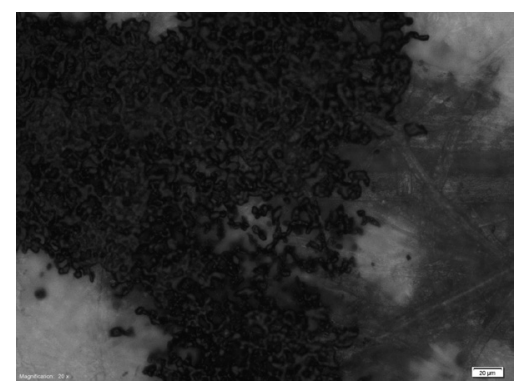

Figure 9. Location of the stamp ink on the stroke of the printed text in the zone of their mutual intersection

However, with the help of such microscopes it is not always possible to determine the relief of the particles of the electrophotographic powder. In this case, the use of a scanning electron microscope (SEM) is effective.

Since the late 1970s, the use of a SEM has been the focus of the research work of experts who have been developing methods for establishing the sequence of making strokes in areas of their intersection. Good results were obtained in determining the sequence of making strokes on heterogeneous parts of intersections of the text printed on typewriters, dot matrix printers, electrophotographic printing devices, and handwritten strokes made with various writing test materials (ballpoint pen pastes, pencils, ink).

In foreign expert laboratories, this method is widely used and successfully improved, especially with the use of high-resolution electron Nowa Kodyfikacja Prawa Karnego 49, 2018 (C) for this edition by CNS 
microscopes, with field emission allowing high-quality stereo images at low voltages (less than $2 \mathrm{mV}$ ).

In the expert laboratories of the Russian Federation, the SEM method has not been widely used, primarily due to their high cost. ${ }^{3}$ The question of the high cost of a SEM can be resolved by renting such a microscope for a specific study in large (often state) organizations. Such a study can help to reveal the surface relief of the particles of the electrophotographic powder on the strokes of the ballpoint pen paste, their integrity or deformation, "bruising" (Fig. 10).
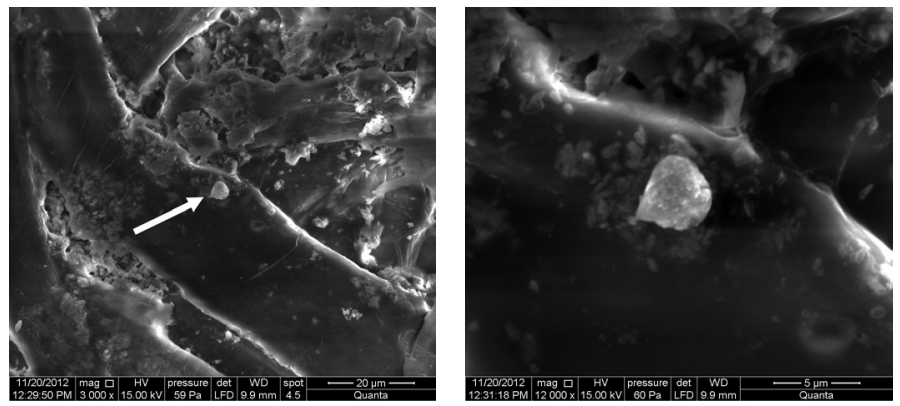

Figure 10. Magnified images of electrophotographic powder particles on the surface of ballpoint pen paste, obtained with a scanning electron microscope FEI Company Quanta 200. The arrow indicates the toner particle located on the signature stroke

In addition, the element map of the studying object allows one to confirm the presence of a particle of the coloring substance of the printed text on the paste stroke (X-ray spectral microanalysis with a special detector on the specified electron microscope is used to analyze the elemental composition). Several elements (aluminum, calcium, silicon, sulfur, iron) are scanned with the help of this method and the achieved maps, as well as spectrograms prove the presence of exactly the particle of the electrophotographic powder on the stroke, not other material (various kinds of contamination, etc.) (Fig. 11-12).

3 M.V. Toropova, Ustanovlenie posledovatel'nosti naneseniya $v$ dokumentah rekvizitov, vypolnennyh elektrofotograficheskim sposobom, rukopisnyh rekvizitov i ottiskov pechatej: Metodicheskie rekomendacii, RFCSE pri Ministerstve yusticii RF, Moskva 2011. 
It is known that particles of electrophotographic powders consist of magnetic metal-containing (iron-containing) particles (most often magnesite) coated with a polymer material (most often silicone). These two main elements - iron (metal) and silicon, which are components of the particles of electrophotographic powders - are detected on the element map (Fig.13a, b).
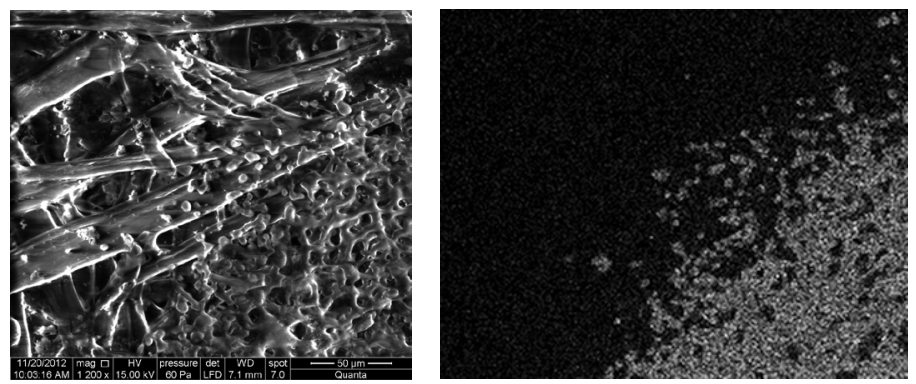

Figure 11. The image of a fragment of a printed text stroke sample in the document obtained by scanning electron microscope FEI Company

Quanta 200 and its element map on iron
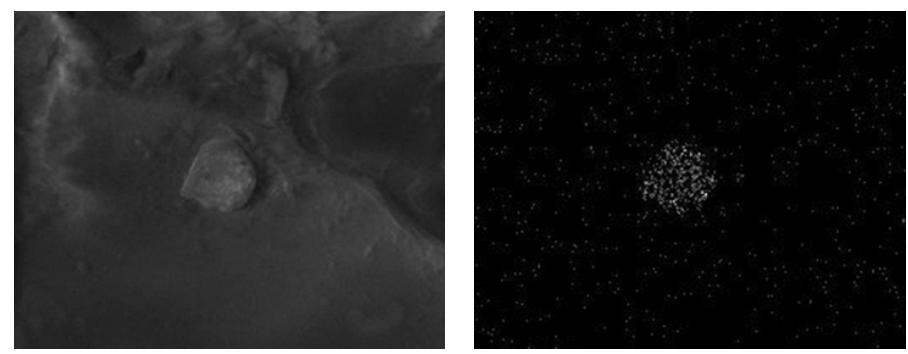

Figure 12. The image of a toner particle and its element map on iron.

The toner particle is located on the signature stroke in the document under study

The investigation with a scanning electron microscope in determining the sequence of application of the requisites of the documents (determining the relative prescription) can improve the reliability of the conclusion and avoid expert errors that are possible when using only direct optical microscopes.

The current/present reality existing in the field of technical research of documents requires their in-depth study with additional methods to- 

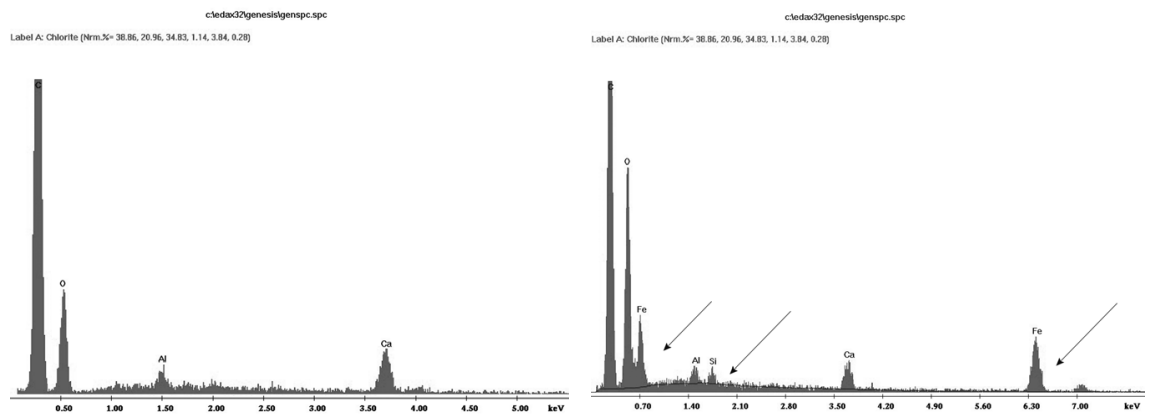

Figure 13. Spectrograms of the elemental composition of the paste stroke of the ballpoint pen (left) and the particles of the electrophotographic powder on the test stroke (right). The arrows indicate the peaks of two- and trivalent iron, and silicon

day. In addition, the method described is non-destructive; therefore, there is an advantage over other methods developed earlier.

An important factor in determining the time of execution of the document is the identification of the presence (absence) of traces of aggressive influence, both on the individual requisites of the document and on the document as a whole. For these purposes, it is obligatory to study the object in the reflected light of an optical microscope at various angles to the light source (including under coaxial illumination ${ }^{4}$ ) in various magnification regimes (from 100 to 600 times). So, for example, an expert can determine the fact of thermal and light (UV-radiation) effects on paper, ink, paste for ballpoint pens, toner of printed text (see Fig. 14-19).

Similarly, the signs of thermal effects on the document are revealed:

- when placing the document in the microwave, in the oven;

- when using water vapor;

- after a document is processed by UV emitters.

The most convincing (evidence-based) picture of traces presence (absence) of aggressive influence on the document is obtained by using an electronic scanning microscope (see Fig. 20-21).

4 M.V. Toropova, V.I. Furletov, "Issledovanie dokumentov podvergshihsya agressivnomu vozdejstviyu (analiz priznakov pri issledovanii peresekayushchihsya shtrihov)", [in:] Sudebnaya ekspertiza: rossijskij i mezhdunarodnyj opyt (materialy mezhdunarodnoj nauchno-prakticheskoj konferencii), Volgograd 2012, pp. 147-151.

Nowa Kodyfikacja Prawa Karnego 49, 2018

(C) for this edition by CNS 


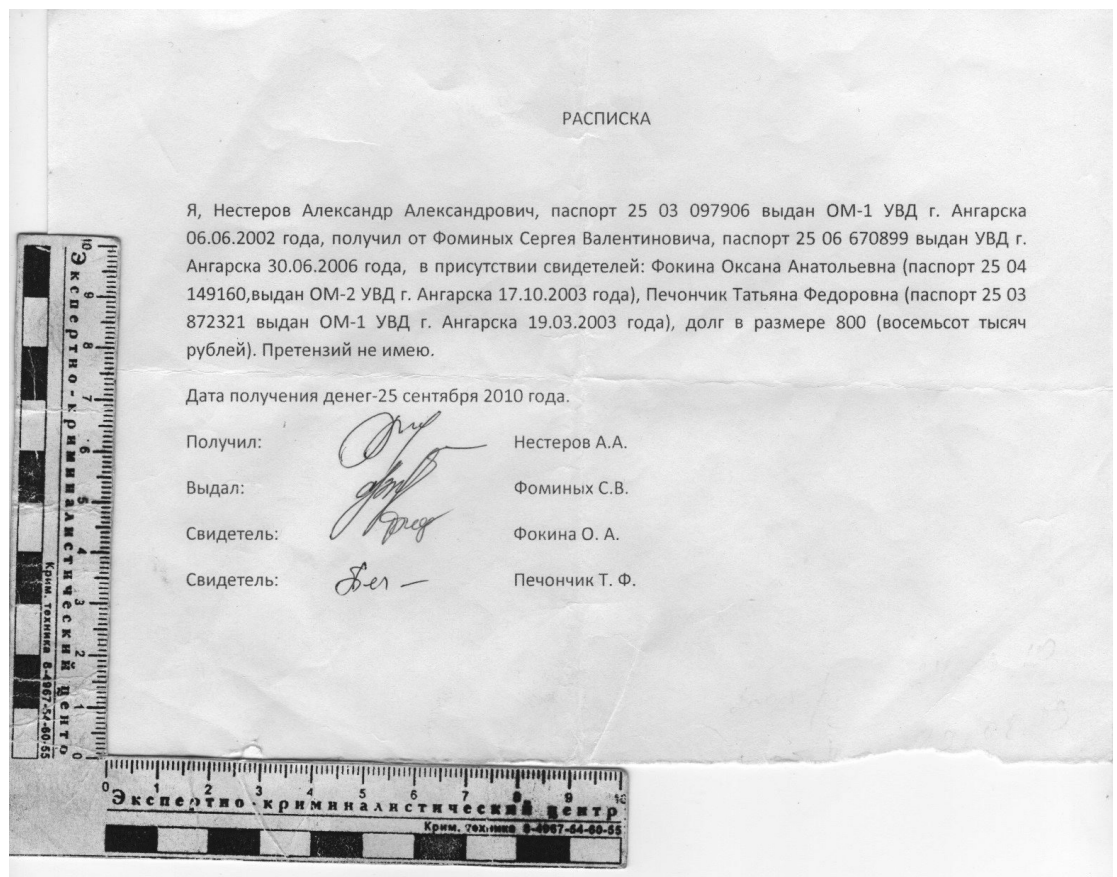

Figure 14. Traces of aggressive (thermal) impact on the document under study with the help of a microwave oven

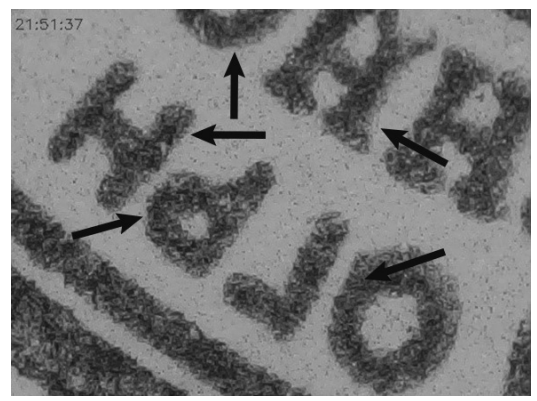

Figure 15. The state of the stamp paint after thermal impact (the arrow indicates the areas of the dye sintering and spreading on the paper in the form of aureola) 


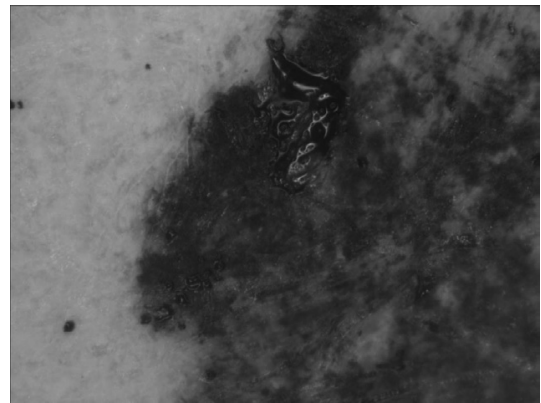

Figure 16. Areas of melting of ballpoint pen paste in the strokes of the signature. The images were taken with an Olympus BX63 microscope

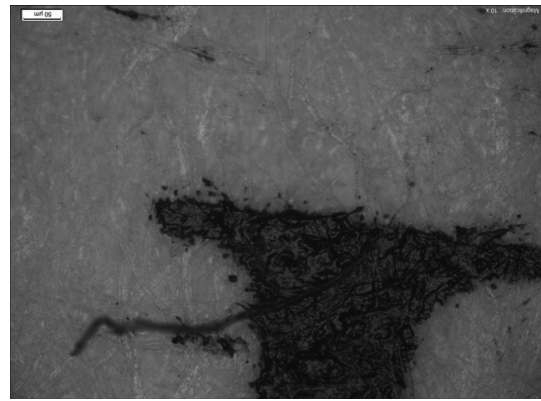

Figure 17. The foreign fibers fused into the coloring substance of the printed text, which appeared as a result of aggressive influence on the document by the iron

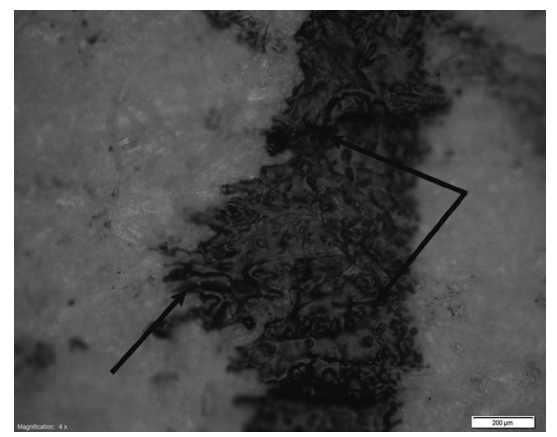

Figure 18. Displacement of the layer of the coloring material of the printed text because of the thermal action of the iron 


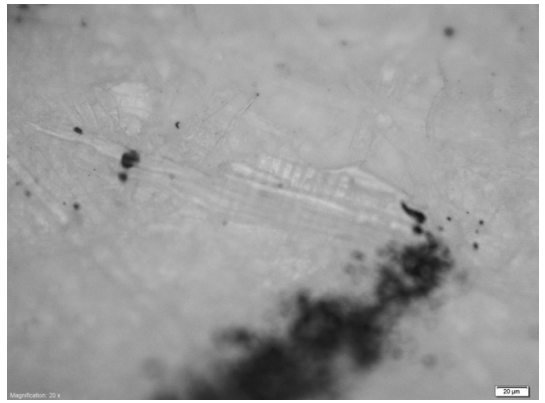

Figure 19. Light effect on the paper of the document, which led to a change in the color of the wood pulp elements

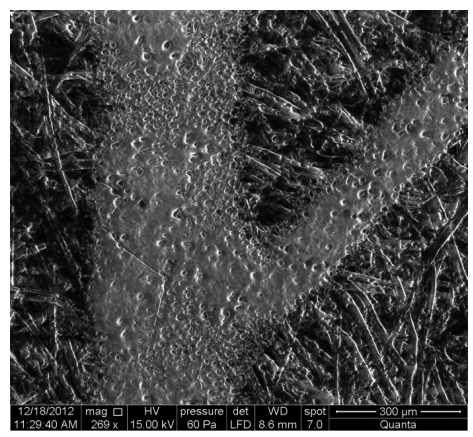

Figure 20. Type of strokes of the printed text made by the laser printer, without any aggressive influence on the document

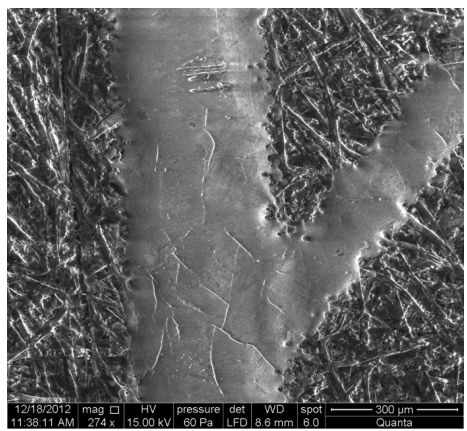

Figure 21. Signs of thermal effects on the printed text of the document, identified with the help of FEI Company Quanta 200 scanning electron microscope 
When considering a trial, a document should be read as a set of typical requisites: text, signature and stamp. ${ }^{5}$ Extracting a particular requisite from the context of the entire document can lead to distorted research results, or give very limited information about the process of creating a document. A qualified expert is obliged to use an integrated approach when examining a document as a whole and its requisites in particular.

With an integrated approach to document research, the expert can use both destructive methods and methods without modifying the document. Thus, being one of the perspective directions of expanding the possibilities of forensic examination, complex expert studies in recent years have had a stable tendency to increase. ${ }^{6}$ Especially this concerns such complex objects of research as documents.

Further in-depth investigation of an integrated approach enhances the possibilities of solving expert problems being a priority for the development of non-destructive methods.

\section{References}

Federatsiya Sudebnyih Ekspertov, http://sud-expertiza.ru/library/sovremennoe-sostoyanie-i-problemy-kompleksnekspertnyh-issledovaniy/ (accessed: 29.09.2018).

Plinatus A.A., "Sovremennye vozmozhnosti tekhniko-kriminalisticheskogo issledovaniya kopij dokumentov, izgotovlennyh posredstvom montazha", [in:] Kriminalisticheskie sredstva i metody v raskrytii i rassledovanii prestuplenij, vol. 2, EKC MVD Rossii, Moskva 2006.

Sosenushkina M.N., Osnovy tekhniko-kriminalisticheskoj ekspertizy dokumentov, VNII MVD SSSR, Moskva 198

Toropova M.V., Ustanovlenie posledovatel'nosti naneseniya $v$ dokumentah rekvizitov, vypolnennyh elektrofotograficheskim sposobom, rukopisnyh rekvizitov i ottiskov pechatej: Metodicheskie rekomendacii, RFCSE pri Ministerstve yusticii RF, Moskva 2011.

Toropova M.V., Furletov V.I., "Issledovanie dokumentov podvergshihsya agressivnomu vozdejstviyu (analiz priznakov pri issledovanii peresekayushchihsya shtrihov)", [in:] Sudebnaya ekspertiza: rossijskij i mezhdunarodnyj opyt (materialy mezhdunarodnoj nauchno-prakticheskoj konferencii), Volgograd 2012.

${ }^{5}$ M.N. Sosenushkina, Osnovy tekhniko-kriminalisticheskoj ekspertizy dokumentov, VNII MVD SSSR, Moskva 1987.

${ }^{6}$ Federatsiya Sudebnyih Ekspertov, http://sud-expertiza.ru/library/sovremennoesostoyanie-i-problemy-kompleksnyh-ekspertnyh-issledovaniy/ (accessed: 29.09.2018).

Nowa Kodyfikacja Prawa Karnego 49, 2018

(C) for this edition by CNS 


\section{Summary}

The purpose of this study is to reveal the advantages of the integrated approach to the fulfillment of expertise in the framework of technical examination of documents (requisites and materials). The authors, using the main research methods (measuring, microscopic, photographic, chromatographic, spectrophotometric, X-ray microanalysis), describe their work experience supporting conclusions with photographs from practical material of the forensic technical examination of documents.

Keywords: questioned document examination, an integrated document study, relative age of execution of the document, microscopic examination, aggressive impact on the requisites of the document. 